\title{
Prolactin-induced mouse mammary carcinomas model estrogen resistant luminal breast cancer
}

Lisa M Arendt ${ }^{1,3}$, Debra E Rugowski ${ }^{1}$, Tara A Grafwallner-Huseth ${ }^{1}$, Maria Jose Garcia-Barchino ${ }^{2,4}$, Hallgeir Rui ${ }^{2}$, Linda A Schuler ${ }^{1 *}$

\begin{abstract}
Introduction: Tumors that express estrogen receptor alpha (ER $\alpha+)$ comprise $75 \%$ of breast cancers in women. While treatments directed against this receptor have successfully lowered mortality rates, many primary tumors initially or later exhibit resistance. The paucity of murine models of this "luminal" tumor subtype has hindered studies of factors that promote their pathogenesis and modulate responsiveness to estrogen-directed therapeutics. Since epidemiologic studies closely link prolactin and the development of ER $\alpha+$ tumors in women, we examined characteristics of the aggressive $E R \alpha+$ and $E R \alpha$ - carcinomas which develop in response to mammary prolactin in a murine transgenic model (neu-related lipocalin- prolactin (NRL-PRL)). To evaluate their relationship to clinical tumors, we determined phenotypic relationships among these carcinomas, other murine models of breast cancer, and features of luminal tumors in women.
\end{abstract}

Methods: We examined a panel of prolactin-induced tumors for characteristics relevant to clinical tumors: histotype, ERa/progesterone receptor (PR) expression and estrogen responsiveness, Activating Protein 1 (AP-1) components, and phosphorylation of signal transducer and activator of transcription 5 (Stat5), extracellular signal regulated kinase (ERK) $1 / 2$ and AKT. We compared levels of transcripts in the ER $\alpha$-associated "luminal" signature that defines this subtype of tumors in women and transcripts enriched in various mammary epithelial lineages to other well-studied genetically modified murine models of breast cancer. Finally, we used microarray analyses to compare prolactin-induced $E R \alpha+$ and $E R \alpha$-tumors, and examined responsiveness to estrogen and the antiestrogen, Faslodex, in vivo.

Results: Prolactin-induced carcinomas were markedly diverse with respect to histotype, ERo/PR expression, and activated signaling cascades. They constituted a heterogeneous, but distinct group of murine mammary tumors, with molecular features of the luminal subtype of human breast cancer. In contrast to morphologically normal and hyperplastic structures in NRL-PRL females, carcinomas were insensitive to ER $\alpha$-mediated signals. These tumors were distinct from mouse mammary tumor virus (MMTV)-neu tumors, and contained elevated transcripts for factors associated with luminal/alveolar expansion and differentiation, suggesting that they arose from physiologic targets of prolactin. These features were shared by ERo+ and ER $\alpha$-tumors, suggesting a common origin, although the former exhibited transcript profiles reflecting greater differentiation.

Conclusions: Our studies demonstrate that prolactin can promote diverse carcinomas in mice, many of which resemble luminal breast cancers, providing a novel experimental model to examine the pathogenesis, progression and treatment responsiveness of this tumor subtype.

\footnotetext{
* Correspondence: schulerl@svm.vetmed.wisc.edu

'Department of Comparative Biosciences, University of Wisconsin-Madison,

2015 Linden Dr., Madison, WI 53706, USA

Full list of author information is available at the end of the article
} 


\section{Introduction}

The hormone, prolactin (PRL), is critical for the development and functional differentiation of the mammary gland [1]. Although its physiologic importance suggests a role in breast carcinogenesis, such activity has been controversial. However, accumulating evidence from a variety of sources now supports a link between this hormone and breast disease. Large prospective epidemiologic studies have correlated circulating levels of PRL with an increased risk of particularly estrogen receptor positive $(\mathrm{ER} \alpha+)$ invasive tumors [2]. Although the relationship between circulating PRL and patient survival has been examined only in smaller studies, higher levels have been associated with tumor aggression, higher risk of metastasis and poor long term survival (reviewed in $[2,3])$. Moreover, the pituitary is not the only source of PRL to the breast. PRL is also expressed within the mammary gland, particularly in humans, permitting autocrine/paracrine actions [4-6]. Recent studies have begun to link genetic variations in the genes for PRL and the prolactin receptor (PRLR) and breast cancer [7-9]. Furthermore, in addition to PRL itself, human growth hormone is also a potent agonist at the PRLR; thus PRLR-transduced signals also may mediate some signals of this other oncogenic hormone [10,11]. Finally, many primary breast tumors, both $E R \alpha+$ and $E R \alpha-$, express the PRLR, pointing to its potential utility as a therapeutic target and prognostic indicator $[4,12,13]$.

Although epidemiological data support a role for PRL in the development and progression of breast cancer, relatively little is known about its contributions to this disease. In order to investigate the pathogenic actions of PRL, we have developed a transgenic mouse model (NRL-PRL), which mimics the high mammary PRL synthesis observed in women. In this model, the PRLand estrogen- insensitive NRL promoter drives expression of the rat PRL transgene in mammary epithelia, exposing the gland to locally elevated PRL $[14,15]$. Nonparous NRL-PRL females develop mammary pathology that exhibits many features of human disease, including early lesions (hyperplasias and intraepithelial neoplasias, similar to ductal carcinoma in situ in women), and eventually, ER $\alpha+$ and ER $\alpha$ - carcinomas. These tumors are locally aggressive, and metastases to local lymph nodes and lungs are occasionally observed [16]. The development of tumors in NRL-PRL females is not dependent on postpubertal ovarian steroids, but is accelerated by supplemental estrogen [17].

Expression of ER $\alpha$ has emerged as the foremost prognostic and therapeutic indicator in primary clinical breast tumors. However, ER $\alpha+$ cancers are themselves very diverse, and many are not susceptible to treatments directed at this pathway. Indeed, $25 \%$ of women treated with tamoxifen will succumb to breast cancer [18]. Large scale transcript profiling of clinical tumors has begun to reveal the basis of ER $\alpha+$ cancer diversity, as well as that of other tumor subtypes defined by pathologic markers (for review, [19]). ER $\alpha+$ tumors share the "luminal" transcript signature, which includes the ER $\alpha$ itself and several other genes linked to ER $\alpha$ expression, as well as defining features such as luminal cytokeratins $[19,20]$. Efforts to resolve luminal tumors into subtypes that predict therapeutic sensitivity have demonstrated elevated expression of proliferation-related genes in patients at higher risk for relapse, which are useful clinically [21-23]. However, these studies have not revealed vulnerabilities that can be therapeutically targeted.

Mouse models have proven to be useful in elucidating the origins of tumor subtypes, and have revealed complex etiologies and relationships to mammary epithelial lineages $[24,25]$. However, the paucity of murine models of $E R \alpha+$ tumors has hindered studies of the factors that give rise to this prevalent tumor subtype and modulate responsiveness to estrogen-directed therapeutics. In light of the epidemiologic evidence linking PRL exposure to the development of ER $\alpha+$ cancers in women, we investigated the phenotype of the mammary carcinomas that develop in NRL-PRL females, with regard to features defining clinical luminal tumors, including expression of the "ER $\alpha$-associated signature", estrogen sensitivity, and activated signaling pathways. Our studies demonstrate that PRL can promote diverse tumor phenotypes, many of which display molecular features of luminal breast cancers, providing insight into the pathogenesis of this cancer subtype.

\section{Materials and methods Reagents}

5-bromo-2-deoxyuridine (BrdU) was obtained from Sigma Chemical Co. (St. Louis, MO, USA), and $17 \beta$ estradiol (E2) was purchased from Steraloids, Inc. (Newport, RI, USA. The following antibodies were used for immunohistochemical analyses: BrdU (MAS-250) from Accurate Scientific (Westbury, NY, USA), proliferating cell nuclear antigen (PCNA; PC 10) and progesterone receptor (PR; A0098) from DAKO Cytomation (Carpinteria, CA, USA), c-Fos (SC-52) and estrogen receptor alpha (ER $\alpha$; SC-542) from Santa Cruz Biotechnology, Inc. (Santa Cruz, CA, USA), pERK 1/2 (Thr202/Tyr204; 9102), pAkt (S473; 3787), and c-Jun (9162) from Cell Signaling Technology (Beverly, MA, USA), pStat5 (AX1) from Advantex BioReagents, LLP (El Paso, TX, USA).

\section{Mouse models}

NRL-PRL mice (line 1655-8, TgN(Nrl-Prl)24EPS) were generated and maintained in the $\mathrm{FVB} / \mathrm{N}$ strain 
background as described [14]. Mice were housed and handled in accordance with the Guide for Care and Use of Laboratory Animals in AAALAC-accredited facilities. All procedures were approved by the University of Wisconsin-Madison Animal Care and Use Committee. p53 $3^{+/-}$heterozygotes [26] that were backcrossed more than 10 generations into the FVB/N strain [27] were used to generate $\mathrm{p} 53^{-1-}$ donors. $\mathrm{p} 53^{-1-}$ mammary epithelial cells (MECs) were transplanted into FVB/N nontransgenic female recipients, and the resulting tumors harvested (manuscript in preparation, O'Leary and Schuler). Mammary tumors from other genetically modified murine models $(\mathrm{FVB} / \mathrm{N})$ were generously provided by Drs. Kim and Alexander (University of Wisconsin) (MMTV-neu [28], and Drs. Green and Zi-Yao Liu (NIH-NCI) (C3(1)-SV40 Tag tumors [29].

\section{Histological examination of mammary tissue}

For some studies, mice were injected with $200 \mathrm{mg} / \mathrm{kg}$ body weight BrdU $1 \mathrm{~h}$ prior to sacrifice to label cells undergoing DNA synthesis. For immunohistochemistry (IHC), deparaffinized slides were exposed to $0.5 \% \mathrm{H}_{2} \mathrm{O}_{2}$ in methanol to block endogenous peroxidase activity, boiled for 15 minutes in $0.1 \mathrm{M}$ citrate $(\mathrm{pH}=6.0)$ or $0.1 \mathrm{M}$ Tris $(\mathrm{pH}=9.0)$ buffer for antigen retrieval, then blocked, and incubated with the primary antibody overnight (for individual antibodies, see Table S1 in Additional File 1). Slides were incubated with the secondary antibody (BioGenex, San Ramon, CA, USA), followed by peroxidase strepavidin and 3,3' diaminobenzidine, and counterstained with hematoxylin. Cells were labeled for PCNA using Vector M.O.M. Basic kit (BMK-2202; Vector Laboratories, Burlingame, CA, USA). pStat 5 was detected as described [30]. Serial sections of tumors were examined for the different endpoints. For all IHC, control sections were stained in parallel (negative controls: omission of primary antibody, irrelevant antibody; positive controls, appropriate for the antibody) as described [14]. To determine labeling indices, 1,000 total cells in at least five randomly chosen microscopic fields in divergent regions of each carcinoma were counted by an investigator blind to the experimental status.

\section{Microarray experiments}

In a preliminary study to compare the tumors that develop in NRL-PRL to other mouse models of mammary cancer, cDNA prepared from tumors was hybridized to Agilent Mouse Oligo Microarrays (Agilent Technologies Inc., Santa Clara, CA, USA) using total RNA from equal numbers of $\mathrm{C} 57 \mathrm{Bl6} / \mathrm{J}$ and 129 male and female pups as the reference sample, as previously described [31]. Data were processed and hierarchical clustering performed, as described [31].
To compare NRL-PRL tumors identified as ER $\alpha$ positive or negative by IHC, total RNA was purified using RNeasy Midi Kits (Qiagen Inc., Valencia, CA, USA) according to the manufacturer's instructions. RNA integrity was assessed using the RNA 6000 Nano Assay and Agilent 2100 Bioanalyzer (Agilent Technologies Inc.). Total RNA $(10 \mu \mathrm{g})$ was reverse transcribed and labeled with Cy5 using the Array 50 kit (Genisphere Inc., Hatfield, PA, USA). MECs were isolated as described [32] from 12-week-old nontransgenic nonparous FVB/N females, for common reference RNA. Reference RNA pooled from 15 mice was reverse transcribed and labeled with Cy3. Tumor and reference samples were co-hybridized overnight to Agilent Mouse cDNA Microarrays (G4104A, 8,614 features), washed, and scanned using Agilent's dual-laser Microarray Scanner (G2565BA) with Feature Extraction Software.

Genes with $\mathrm{Cy} 3$ and $\mathrm{Cy} 5$ intensity values higher than 100 were considered as expressed genes and were normalized with lowess smoother followed by log base 2 transformation. Values that changed at least 1.5 -fold in either direction from the gene's median value were included in the class comparison. Genes differentially expressed between ER $\alpha$ positive and negative classes were determined with a significance threshold of univariate tests at $P<0.01$. Average linkage hierarchical clustering on both the genes and samples was performed using the gene list generated by class comparison. Analyses were performed using BRB ArrayTools (version 3.6.0) developed by Dr. Richard Simon and Amy Peng Lam (Biometric Research Branch, National Cancer Institute). These data have been deposited in the public database, ArrayExpress (E-MEXP-3013).

\section{Real-time PCR}

RNA from tumors and MECs was examined using quantitative real time PCR (qRT-PCR). cDNA was synthesized from $1 \mu \mathrm{g}$ RNA using random hexamers (Amersham Biosciences, Piscataway, NJ, USA) and MMLV Reverse Transcriptase (Promega, Madison, WI, USA), and qRT-PCR performed as described [17]. Negative (no cDNA) and positive controls were included with each plate. Specific primer sequences are listed in Table S2 in Additional File 1. Results were calculated using the comparative $C_{T}$ method and normalized to $18 \mathrm{~S}$ RNA, and data were analyzed for statistical significance as described in the figure legends.

\section{Tumor sensitivity to ovarian steroids}

To examine the responsiveness of tumors to circulating ovarian steroids, tumors were allowed to develop until they reached $1.5 \mathrm{~cm}$ in diameter. About one-third of the tumor mass was then removed, concomitant with ovx or sham surgery, or ovx and subcutaneous treatment 
with $0.1 \mathrm{mg}$ pellets of $17 \beta$-estradiol (E2; Innovative Research of America, Sarasota, FL, USA), which result in plasma levels of 50 to $75 \mathrm{pg} / \mathrm{ml}$ [33]. Tumors were measured twice weekly with calipers, and tumor volume was calculated (the largest diameter $\mathrm{x}$ (the smallest diameter $)^{2} \times 0.4$ ). Mice were humanely euthanized and tissue collected when the tumors reached $1.5 \mathrm{~cm}$ in diameter. Histological comparisons of the tumor biopsies and end stage tumors were carried out as above.

For some experiments, $1 \mathrm{~mm}^{3}$ NRL-PRL tumor fragments were transplanted bilaterally into fourth inguinal mammary glands of 12-week-old nontransgenic syngeneic $\mathrm{FVB} / \mathrm{N}$ hosts. After the tumors grew to $0.75 \mathrm{~cm}$ in diameter, recipient females were treated with ovx, sham surgery, or sham surgery and weekly subcutaneous injections of $5 \mathrm{mg}$ Faslodex (ICI 182,780; AstraZeneca, Wilmington, DE, USA). Tumors were measured and collected as described above.

\section{Statistical analyses}

Statistical analyses were performed using Prism v.4.03 (GraphPad Software, Inc., San Diego, CA, USA). Differences were considered significant at $P<0.05$.

\section{Results and discussion}

Locally elevated PRL leads to histologically diverse ER $\alpha$ positive and $E R \alpha$ negative carcinomas

NRL-PRL nonparous females develop diverse invasive mammary carcinomas with a long latency [14]. In order to examine the breadth of tumor phenotypes promoted by this prolonged PRL exposure, we examined a panel of 39 of these tumors (mean latency $+/$ - standard deviation (S.D.), $18.2+/-3.6$ months). The majority were adenocarcinomas of several histotypes; carcinosarcomas constituted a minor population (Figure 1, Table 1). These carcinomas varied widely in the proportion of cells that expressed detectable ER $\alpha$ (0 to 79\%). Nineteen of the 39 tumors examined exhibited greater than $10 \%$ $\mathrm{ER} \alpha+$ cells, a common clinically used threshold. The majority did not express detectable progesterone receptor (PR); only four tumors demonstrated PR immunostaining in more than $5 \%$ of the tumor cells. The morphological heterogeneity suggests cooperation between PRL and other oncogenic factors during the long period of development of these tumors, similar to that which may occur in women.

\section{PRL-induced tumors display inverse Stat5 and AP-1 activation and elevated epithelial PAKT}

PRL can activate multiple signaling cascades, which may play distinct roles in its physiologic and pathogenic actions in the mammary gland. In order to determine the relationship of these signals to tumor characteristics, we examined the activation of these pathways in the

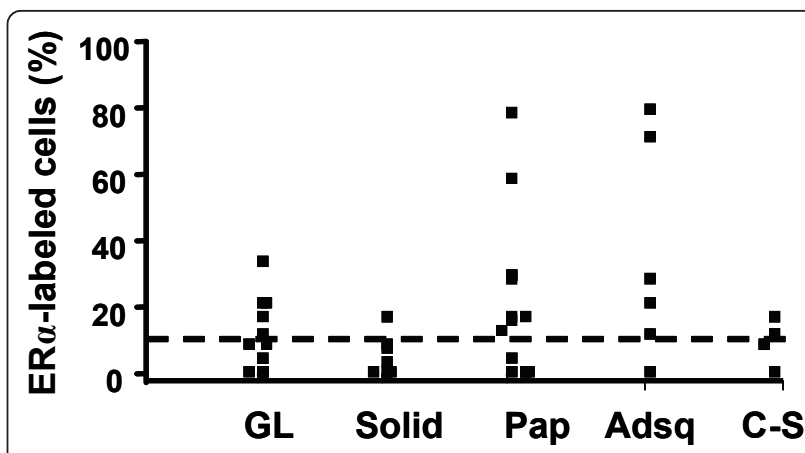

Figure 1 Mammary carcinomas that develop in NRL-PRL females exhibit diverse histotypes, and express varying levels of ER $\alpha$. The proportion of cells containing immuno-detectable ER $\alpha$ was quantitated as described in Materials and methods, and shown related to tumor histotype. Each box represents a single tumor that arose in a different NRL-PRL nonparous female. The dashed line marks 10\% ER $\alpha+$ cells, a common clinically used threshold. (Tumor histotypes: GL, glandular; Pap, papillar; Adsq, adenosquamous; C-S, carcinosarcoma).

panel of PRL-induced tumors by IHC. Signal transducer and activator of transcription 5 (Stat5) is one of the best characterized mediators of PRL activity, and is critical for PRL-induced alveolar development during pregnancy (for review, $[1,34]$ ). The tumors that developed in NRLPRL females contained variable proportions of cells with nuclear pStat5 (range: 4.2 to $93.3 \%$ ), which was not related to ER $\alpha$ levels (Figure 2a, d, $P>0.05$ ). Although many glandular and solid tumors exhibited relatively high proportions of cells containing nuclear pStat5, evidence for activation of this pathway varied substantially even among these histotypes. Many adenocarcinomas demonstrated low nuclear pStat5, as did all of the poorly differentiated carcinosarcomas (Table 1).

PRL can also initiate other signals, including several MAP kinases, which are elevated in mammary lysates of NRL-PRL females [17], and are particularly strongly activated in some breast cancer cells lines [35]. PRLactivated MAP kinases can increase synthesis and phosphorylation of multiple Activating Protein-1 (AP-1) components, activating the AP-1 transcriptional enhancer [36]. AP-1 target genes have been shown to enhance cellular proliferation, survival, and invasion (for review, [37-39]). Both c-Fos and c-Jun were variably expressed in PRL-induced tumors (Figure 2b, c, e). Their expression was directly related to each other (data not shown, $P=0.005, \mathrm{R}=0.83$ ). Although adenosquamous carcinomas and carcinosarcomas had the highest levels of c-Fos expression, a large subset of other histotypes also displayed significant staining (Table 1). Interestingly, nuclear pStat 5 levels were negatively correlated with both c-Fos (Figure 2e; $P<0.0001, \mathrm{R}=-0.63$ ) and c-Jun (data not shown; $P=0.0058, \mathrm{R}=-0.82$ ). The inverse 
Table 1 Characteristics of PRL-induced carcinomas by histotype

\begin{tabular}{|c|c|c|c|c|c|}
\hline & Glandular & Solid & Papillary & Adenosquamous & Carcinosarcoma \\
\hline $\mathrm{N}$ & 10 & 3 & 10 & 3 & 4 \\
\hline$E R \alpha^{1}$ & $10.0 \pm 3.6^{a}$ & $4.4 \pm 2.9^{b}$ & $21.1 \pm 8.1$ & $32.2 \pm 10.2^{a, b}$ & $8.2 \pm 3.0$ \\
\hline $\mathrm{PR}^{1}$ & $1.5 \pm 1.0$ & $0.3 \pm 0.2$ & $13.8 \pm 6.3$ & $2.4 \pm 1.4$ & 0 \\
\hline pStat $5^{1}$ & $49.0 \pm 8.13^{a, b}$ & $66.6 \pm 12.2^{c, d, e}$ & $29.4 \pm 18.7^{c}$ & $23.9 \pm 5.25^{\mathrm{a}, \mathrm{d}}$ & $5.7 \pm 1.9^{b, e}$ \\
\hline c-Fos ${ }^{1}$ & $18.3 \pm 2.8^{a}$ & $15.0 \pm 2.5^{\mathrm{b}, \mathrm{c}}$ & $17.6 \pm 3.7^{d}$ & $30.5 \pm 4.4^{\mathrm{a}, \mathrm{b}}$ & $25.2 \pm 3.2^{c, d}$ \\
\hline S phase ${ }^{1}$ & $15.6 \pm 1.7$ & $15.0 \pm 2.5$ & $18.0 \pm 2.0$ & $14.7 \pm 1.3$ & $15.5 \pm 2.2$ \\
\hline Apoptotic $^{1}$ & $2.1 \pm 0.3$ & $3.6 \pm 1.1$ & $2.2 \pm 0.3$ & $1.9 \pm 0.4$ & $1.1 \pm 0.2$ \\
\hline pERK $1 / 2^{2}$ & $\begin{array}{l}70 \% \text { strong, } 10 \% \text { weak stromal; } \\
30 \% \text { epithelial }\end{array}$ & $\begin{array}{l}100 \% \text { strong } \\
\text { stromal }\end{array}$ & $\begin{array}{l}90 \% \text { strong stromal; } 10 \% \\
\text { epithelial }\end{array}$ & $100 \%$ strong stromal & $\begin{array}{l}100 \% \text { strong stromal } \\
\& \text { epithelial }\end{array}$ \\
\hline $\mathrm{pAKT^{2 }}$ & $\begin{array}{l}50 \% \text { epithelial; } 20 \% \text { stromal; } \\
30 \% \text { negative }\end{array}$ & $\begin{array}{l}\text { 67\% epithelial; } 33 \% \\
\text { negative }\end{array}$ & $\begin{array}{l}\text { 70\% epithelial; } 10 \% \text { stromal; } \\
20 \% \text { negative }\end{array}$ & $\begin{array}{l}33 \% \text { epithelial \& stromal; } \\
67 \% \text { negative }\end{array}$ & $\begin{array}{l}75 \% \text { epithelial; } 25 \% \\
\text { negative }\end{array}$ \\
\hline
\end{tabular}

${ }^{1} \%$ tumor epithelial cells that are positive, mean \pm s.e.m (see Materials and methods). Same lower case letters indicate significant differences between histotypes $(P<0.05 ;$ Students $t$-test).

${ }^{2} \%$ of tumors of each histotype that displayed strong staining in different locations (stroma, epithelium, or both) as indicated.

ER $\alpha$, estrogen receptor alpha; ERK, extracellular signal regulated kinase; PR, progesterone receptor; PRL, prolactin; Stat5, signal transducer and activator of transcription 5 .

relationship of these signals in primary NRL-PRL tumors is consistent with our previous observation of PRL signals to Stat 5 and AP-1 in several breast cancer cell lines [35].

The higher level of nuclear pStat 5 in well-differentiated PRL-induced carcinoma histotypes resembles the association of pStat 5 with features of more differentiated clinical breast tumors (for review, [34]). In order to examine the association of this pathway with molecular phenotype in adenocarcinomas, we examined levels of two transcripts associated with distinct mammary behaviors. The 5 PRL-induced adenocarcinomas with highest nuclear pStat5 (70 to 93\%) and low c-Fos had significantly elevated transcripts for the proteinase inhibitor, Expi, compared to those adenocarcinomas with lowest pStat5 (4 to $10 \%$, Figure 2f, $P=0.003$ ). Expi expression increases in early pregnancy [40], and is reduced in PRLR $^{-1-}$ mammary glands [41]. In contrast, the adenocarcinomas with lowest nuclear pStat 5 contained elevated mRNA for the metalloproteinase, $M m p 9$ (Figure $2 \mathrm{~g} ; P=0.03$ ), which in women is associated with high tumor grade, metastasis, and reduced survival [42], consistent with a more aggressive phenotype.

Elevation of phosphorylated extracellular signal regulated kinases $1 / 2$ (pERK1/2) is found in some clinical tumors in women [43], and is increased in lysates of NRL-PRL mammary glands [17]. The location of pERK1/2 varied substantially among PRL-induced tumors. The majority of the adenocarcinomas (68\%) demonstrated strong stromal staining with rare nuclear staining in epithelial cells (Table 1, Figure 3a). In contrast, all of the carcinosarcomas in the panel displayed both strong epithelial nuclear and cytoplasmic labeling (Figure 3b, c). This histotype had significantly higher levels of Vim (Figure 3h), but similar levels of Krt8 transcripts compared to the adenocarcinomas (Figure 3i).
The spindle shaped cell morphology, loss of cell polarity, and expression of Vim mRNA within these tumors suggest the epithelial to mesenchymal transition (EMT, for review, $[44,45])$. Significantly enhanced levels of $M m p 9$ transcripts were also detected in these tumors (Figure 3j).

The PI3K/AKT pathway also has been associated with proliferation, survival, and EMT in human breast tumors, as well as resistance to endocrine therapy [46-48]. pAKT is also elevated in mammary glands of NRL-PRL females [17]. The majority of the carcinomas in this panel displayed strong pAKT labeling in both the nuclei and cytoplasm of tumor epithelium (Table 1, Figure 3d). Other tumors exhibited pAKT labeled cells in both the stroma and epithelium, and a minority in the stromal compartment alone (Figure 3e). Unlike pERK1/2, pAKT expression was not correlated with a specific histotype; carcinosarcomas demonstrated variable expression levels of nuclear and cytoplasmic pAKT (Figure 3f, g).

Together, these observations suggest that a broad spectrum of signals may contribute to progression of these carcinomas. Nuclear pStat5 is elevated in hyperplastic lesions in NRL-PRL glands [17], and early ablation of Jak2 protects against PRL-induced tumors [49], consistent with an important role for the Jak2-Stat5 pathway in their genesis. However, the data presented here indicate that high pStat5 persists in only a minor subset of established PRL-induced carcinomas, suggesting that other signals drive progression of most of these tumors. Elevated activities of AP-1 [50,51], AKT [52] and MAP kinases, including ERK1/2 [43], have been implicated in resistance to conventional chemotherapies and anti-estrogens. PRL can activate these signals alone, as well as potently cooperate with growth factors to enhance ERK1/2 and AKT activation in vitro and in vivo [53-55]. In light of the variable levels of Prlr 

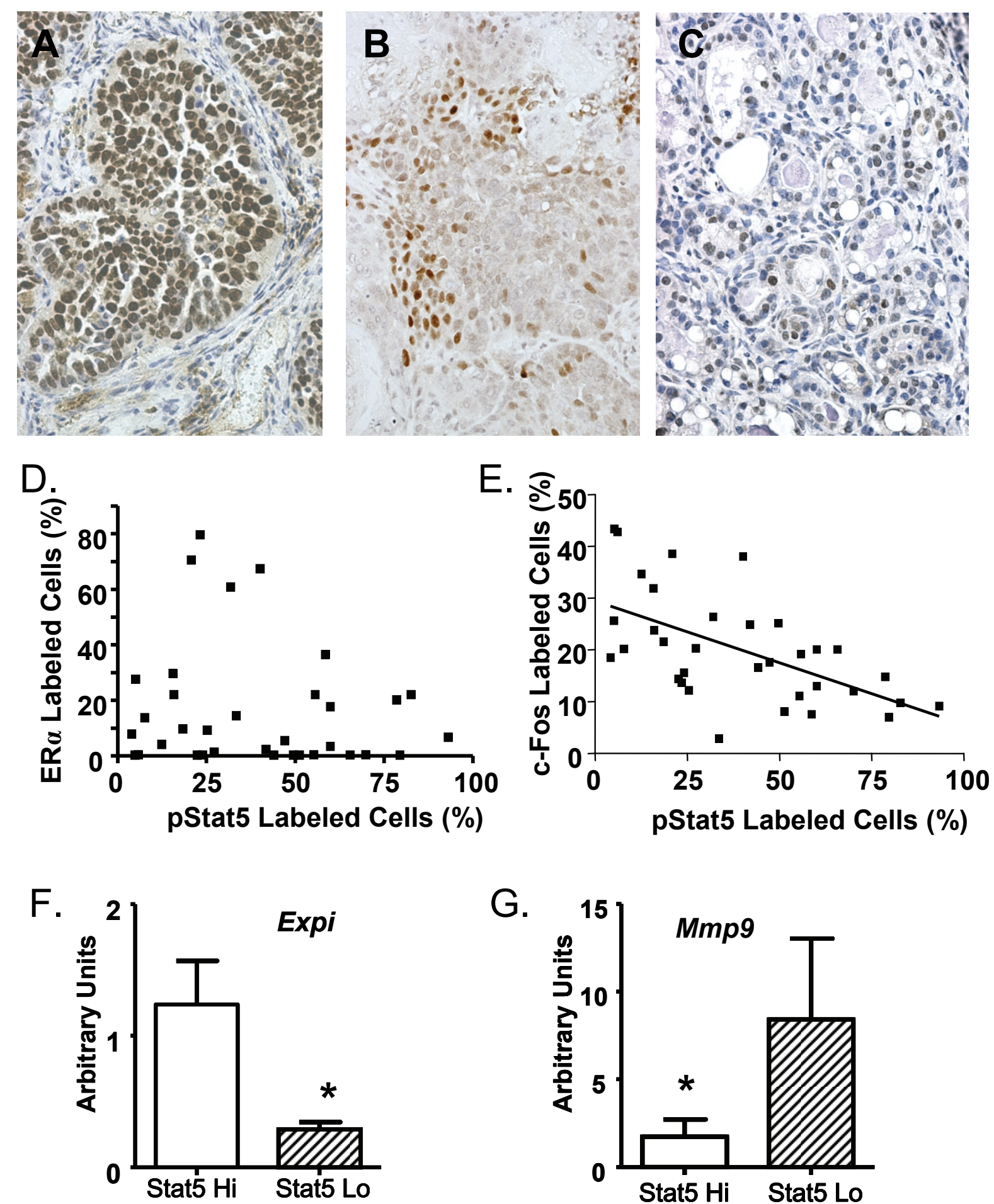

Figure 2 PRL-induced carcinomas demonstrate an inverse relationship between nuclear phosphorylated Stat 5 (pStat 5) and AP-1 proteins. (a) Nuclear pStat 5 staining in a glandular adenocarcinoma. (b) c-Fos expression in a glandular adenocarcinoma. (c) c-Jun staining in a glandular adenocarcinoma. (d) The proportion of tumor cells that express ER $\alpha$ and nuclear pStat5 is not correlated. (e) Carcinomas exhibit a significantly negative correlation between the proportion of cells that contain nuclear pStat 5 and c-Fos $(P<0.0001, R=-0.63)$. ER $\alpha$, pStat $5, c-$ Fos and c-Jun expression were evaluated and quantitated as described in Materials and Methods. Each box represents a single carcinoma that arose in a different NRL-PRL nonparous female. Correlations were determined using Spearman's non-parametric test. (f)Expi mRNA is significantly increased in the adenocarcinomas expressing highest pStat5, compared to the lowest 5 (mean \pm s.e.m., $N=5$; ${ }^{*}, P=0.003$ ). (g)Mmp9 mRNA is significantly decreased in the adenocarcinomas expressing highest pStat5, compared to the lowest 5 (mean \pm s.e.m., $N=5 ;{ }^{*}, P=0.03$ ). (f, g) Transcript levels were measured using qRT-PCR as described in Materials and Methods. Original magnification: a, b, c, 400x. 

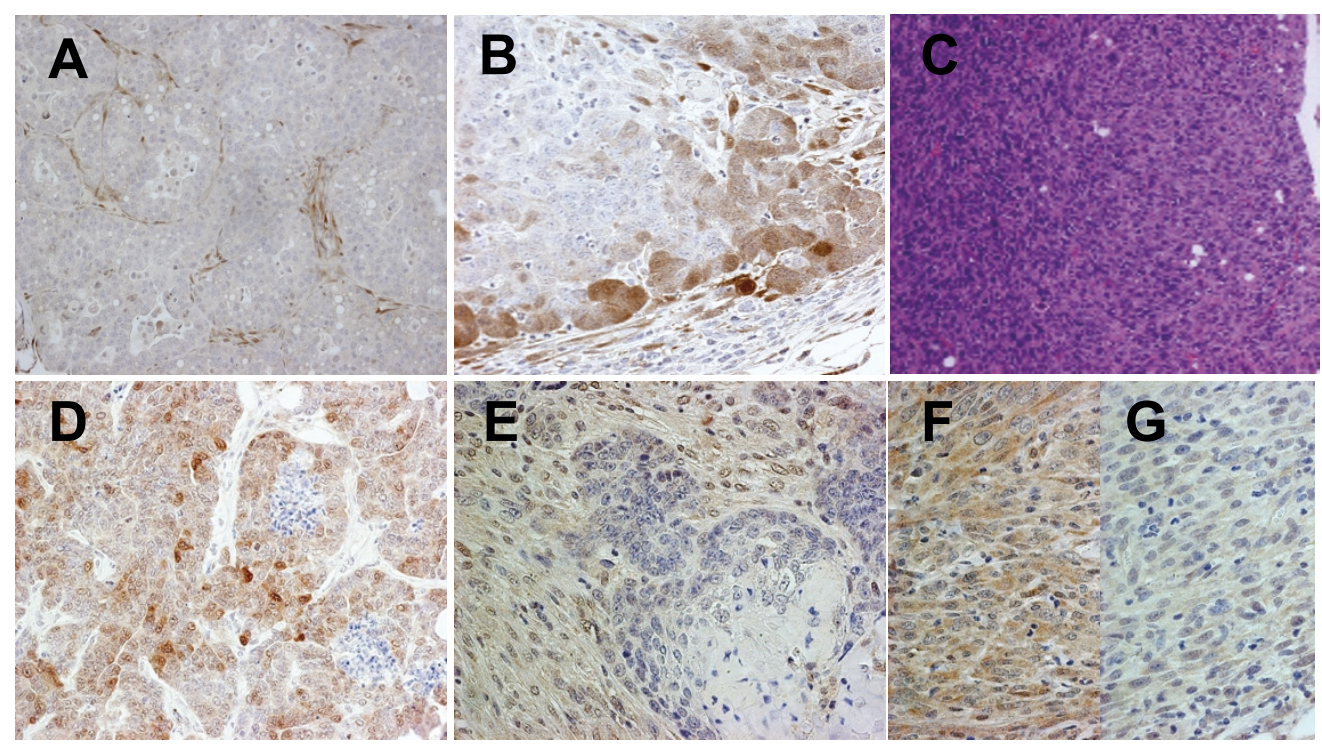

\section{H. Vimentin}

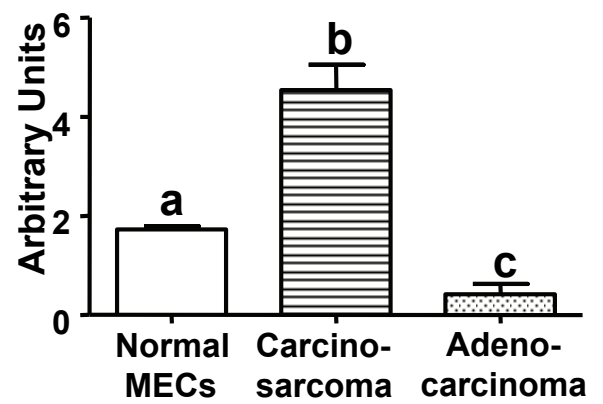

I. Keratin 8

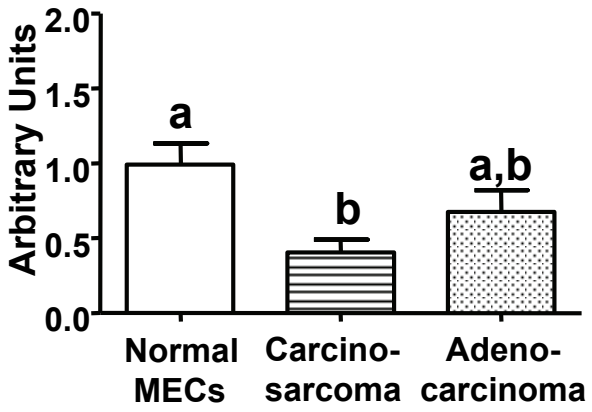

\section{J. $M m p 9$}

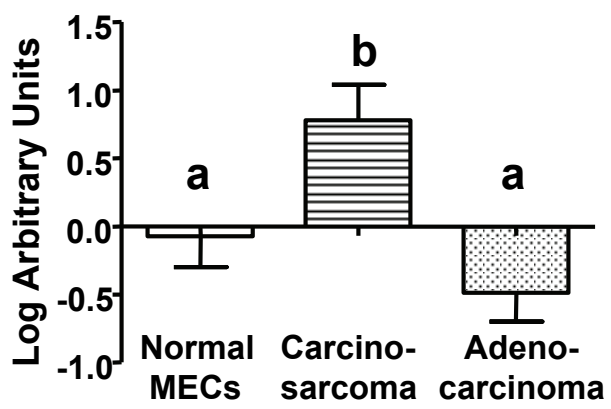

Figure 3 Adenocarcinomas exhibit activated ERK1/2 in stroma and AKT in epithelia; carcinosarcomas display strong epithelial pERK1/ 2. (a) pERK1/2 localized in stromal cells of differentiated glandular adenocarcinomas. (b) Mammary carcinosarcomas demonstrated nuclear and cytoplasmic staining for pERK1/2. (c) Carcinosarcoma from gland of NRL-PRL female (hematoxylin and eosin stain). (d) Glandular adenocarcinoma from NRL-PRL female demonstrating nuclear and cytoplasmic staining for PAKT. (e) pAKT localized primarily in the stroma of a squamous adenocarcinoma. (f, g) Carcinosarcomas demonstrated variable levels of pAKT expression. (h) Carcinosarcomas demonstrated significantly higher levels of vimentin mRNA compared to either morphologically normal MECs or more differentiated adenocarcinomas from NRL-PRL females. (i) Carcinosarcomas had similar levels of keratin 8 transcripts compared to adenocarcinomas. (j)Mmp9 mRNA was significantly increased in carcinosarcomas. Transcript levels were measured using QRT-PCR as described in Materials and Methods and represented as mean \pm s.e.m. (MECS, $N=3$ samples, each containing RNA pooled from 5 mice; carcinosarcomas, $N=4$; adenocarcinomas with high pStat5, $N=5$ ). Letters denote significant differences using ANOVA, followed by Newman-Keuls post test $(P<0.05)$. Original magnification: a, c, 200x; b, d, e, f, g, 400x. 
transcripts in these tumors (see below), it is clear that PRL itself may play different roles in ongoing activation of these pathways as they influence lesion progression, tumor phenotype, and treatment sensitivity.

\section{PRL-induced carcinomas share molecular features of luminal tumors in women}

To evaluate shared characteristics of PRL-induced carcinomas, in a preliminary study we examined the transcript profiles of six NRL-PRL carcinomas, including three each of the most prevalent histotypes (glandular and papillary), expressing variable levels of ER $\alpha$ (three positive, three negative by IHC, not associated with histotype). Unsupervised hierarchical clustering based on an intrinsic gene list developed for murine models [31] showed that the NRL-PRL tumors formed a distinct subgroup neighboring MMTV-neu tumors.

To compare the phenotype of NRL-PRL tumors more closely to other well-studied genetically modified murine models of breast cancer subtypes in the FVB/N strain background, we compared levels of transcripts for ER $\alpha$ associated genes in the "luminal" signature [20] and those enriched in various mammary epithelial lineages. MMTV-neu tumors model clinical HER2+ tumors. Like both human HER2+ tumors [25] and other murine tumors that develop in response to MMTV-driven oncogenes [31], MMTV-neu tumors display some characteristics of the "luminal" tumor subtype in women. Tumors in this extensively studied mouse model do not express ER $\alpha$ or FoxA1, a transcription factor which coregulates many targets [56,57]. However, they do express other ER $\alpha$-associated genes, including Xbp1 and Gata 3 [58-60]. In contrast, tumors that develop in both C3(1)SV40 Tag females and transplanted $\mathrm{p} 53^{-/-}$models have many features of "basal" tumors in women $([31,61]$, O'Leary and Schuler, in prep).

Unlike the morphologically homogeneous MMTV-neu tumors, levels of transcripts that mark luminal breast cancers varied in NRL-PRL carcinomas, consistent with the diverse tumors in this model (Figure 4, Figure S1 in Additional File 1). In contrast to the majority of murine models, PRL-induced adenocarcinomas expressed relatively high levels of Esr1 mRNA, although as predicted from the IHC, levels varied considerably (Figure 4a). PRL-induced papillary carcinomas also contained comparatively high levels of the ER $\alpha$-associated transcripts in the luminal signature, including FoxA 1 and $X b p 1$ (Figure 4b, c). Gata3 mRNA was readily detectably in NRL-PRL tumors, but levels were lower than in MMTV-neu tumors (Figure 4d). Although Gata3 specifies ductal/alveolar cell fate and is markedly reduced in Prlr $^{-1-}$ glands [1], this transcription factor also maintains luminal differentiation and is reduced in invasive breast cancer [62], consistent with the less differentiated phenotype of the PRL-induced carcinomas.

In light of the luminal phenotype of many tumors promoted by PRL, we examined levels of transcripts associated with distinct mammary subpopulations and differentiation processes $[24,63]$. PRL-induced tumors displayed relatively high levels of Itga6 (encoding integrin $\alpha 6$, CD49f) mRNA, a marker for stem cell and progenitor populations (Figure 5a). They expressed relatively low levels of transcripts for both Itgb1 (encoding integrin $\beta 1$, CD29), which marks stem cell and basal but not luminal subpopulations (Figure 5b), and also Itgb3 (encoding integrin $\beta 3, \mathrm{CD} 61$ ), a marker for luminal progenitors (Figure $5 \mathrm{c}$ ). In contrast, three of the four NRL-PRL adenocarcinomas displayed relatively high levels of CD44 (Figure 5d), an adhesion molecule associated with stem cells and metastasis $[64,65]$. NRL-PRL adenocarcinomas also contained elevated mRNA for several transcription factors, which direct luminal/alveolar cell expansion and differentiation, are co-expressed with PRLR in many normal MECs, and are linked to PRL in genetic models $[1,66]$. PRL-induced adenocarcinomas contained relatively high levels of mRNA for Elf5, a PRL-induced factor that directs the alveolar lineage [67], as well as CEBP $\beta$, a transcriptional regulator which has been implicated in stem cell and luminal progenitor repopulation [68] (Figure 5e, f). Consistent with their roles in luminal cell commitment, individual genetic ablations of Gata3, Elf5, C/EBP $\beta$ and also Stat5 have been shown to alter the size of the MEC subpopulation expressing integrin $\beta 3(\mathrm{CD} 61+)$, which is enriched in luminal precursors. However, the variable direction and timing of the observed changes reflect their complex actions at more than one stage of this process $[24,68,69]$. Future studies will elucidate the effect of PRL on mammary epithelial subpopulations and roles of these transcriptional regulators in its actions, and illuminate differences in cellular origin and/or pathways of progression from MMTV-neu tumors and among the different histotypes of PRL-induced carcinomas.

Transcripts for the cdk4/6 inhibitor, $C d k n 2 c$ $\left(\mathrm{p} 18^{\mathrm{INK} 4 \mathrm{c}}\right)$, were very low (Figure $5 \mathrm{~g}$ ). Genetic ablation of this tumor suppressor induces well-differentiated non-invasive luminal tumors in mouse models [70]. Similar results were observed for $C d k n 2 a\left(\mathrm{p} 16^{\mathrm{INK} 4 \mathrm{a}}\right.$, data not shown). These results are consistent with the similar mammary phenotypes of $\mathrm{Prlr}^{-/-}$and $C \mathrm{Cnd1^{-/- }}$ mice [1], and ability of PRL to increase cyclin D1 transcription [71], and support a key role for cdk4/6 in PRL-induced tumorigenesis.

PRL also may contribute to the tumor phenotype of other models; some C3(1)-SV40 Tag as well as MMTVneu tumors contained appreciable Prlr mRNA (Figure 5h). 


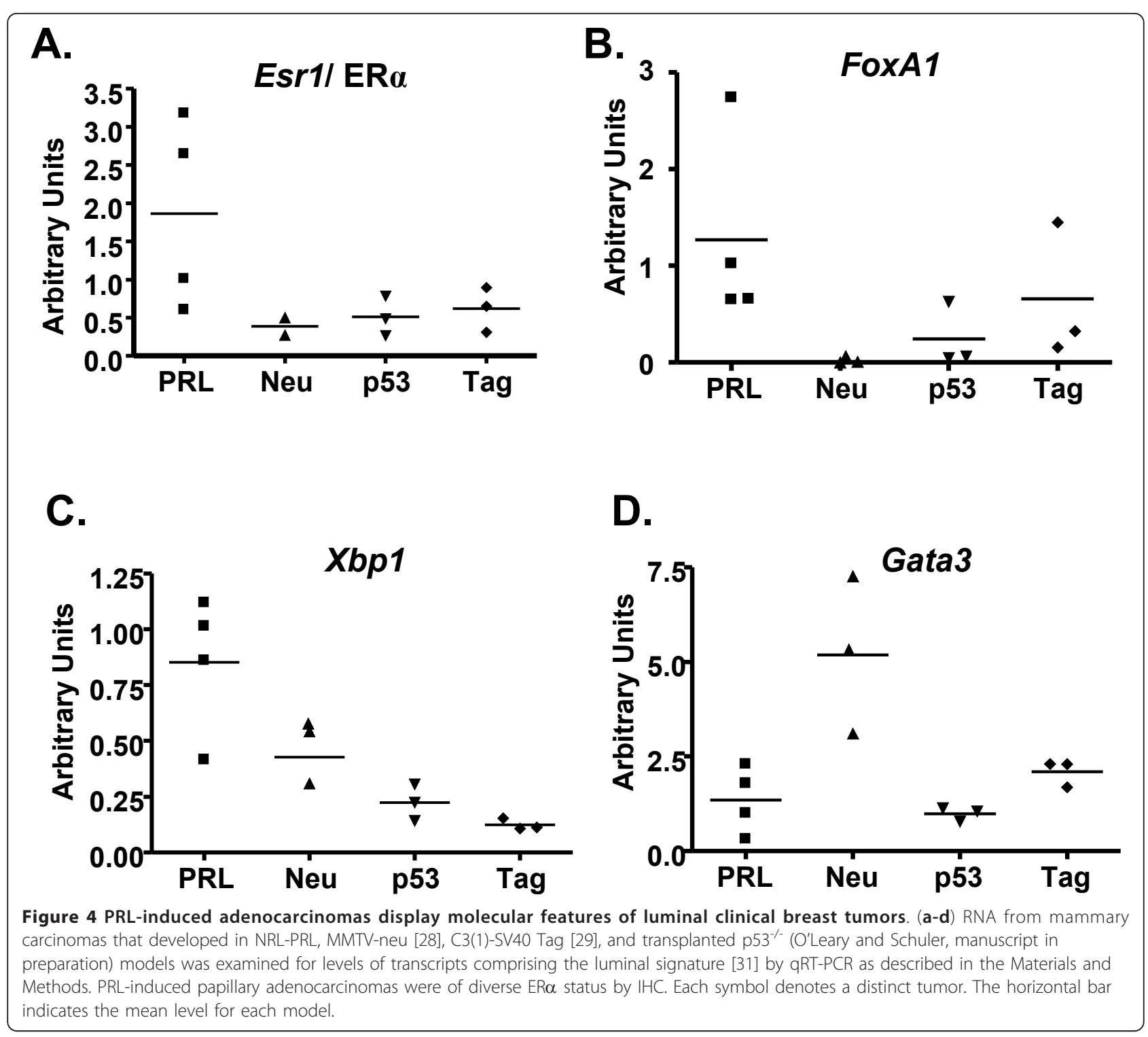

The CD61+ progenitor population has recently been shown to be the origin of basal tumors [72]; the size of this MEC subpopulation is strongly modulated by Stat 5 . These observations invite speculation on potential therapeutic or preventative approaches directed at PRL action in multiple tumor types.

These marked differences in the molecular phenotype of PRL-induced tumors compared to other genetically modified mouse models of breast cancer suggest that PRL acts on its physiological target cells to promote diverse luminal-type tumors, but raises questions about the identity of these cells, the role of mediators associated with "normal" function in tumor progression, and factors contributing to tumor heterogeneity. Development of additional markers for the various mammary epithelial subpopulations, and antibodies that recognize the native conformation of the murine PRLR will assist in determining the characteristics of the precursors of luminal tumors, and identifying the target cells of PRL in this process.

$E R \alpha$ expression is associated with distinct molecular features, but does not confer estrogen responsiveness In our preliminary studies comparing PRL-induced tumors to other murine models of breast cancer, PRLinduced ER $\alpha$ - and ER $\alpha+$ tumors clustered together, indicating shared features suggesting a common origin. In order to determine characteristics of PRL-induced tumors that are associated with differences in ER $\alpha$ protein expression, we compared transcript profiles from four $E R \alpha+$ and four $E R \alpha$ - adenocarcinomas (determined by IHC) of divergent histotypes that did not segregate 


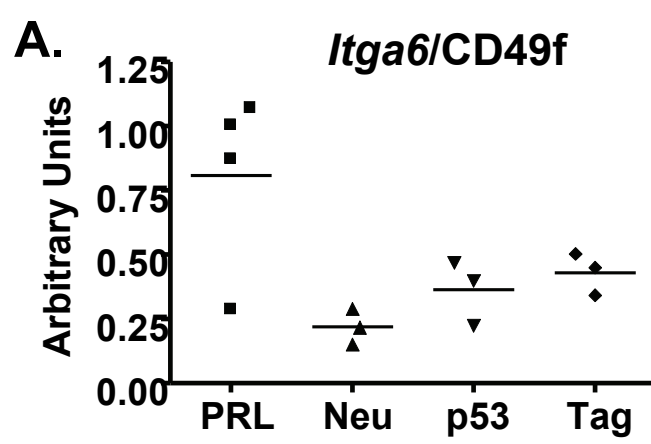

B.

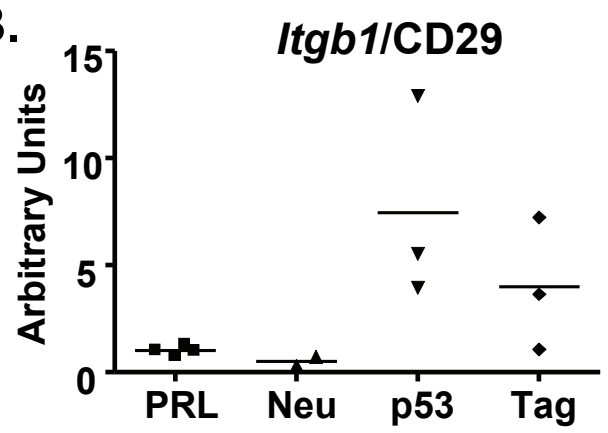

C.

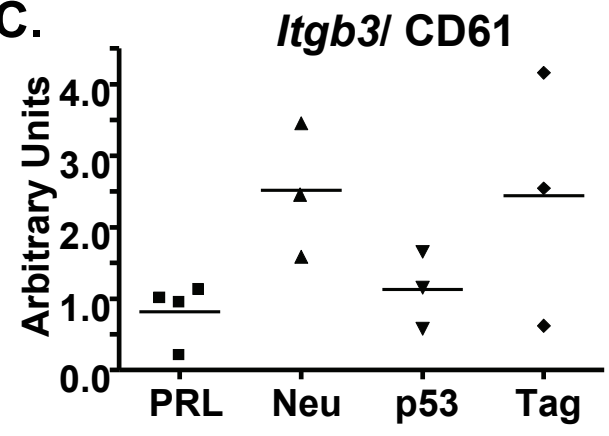

E.

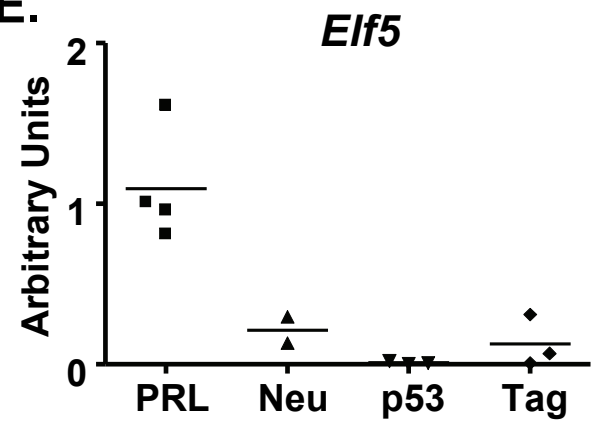

G.

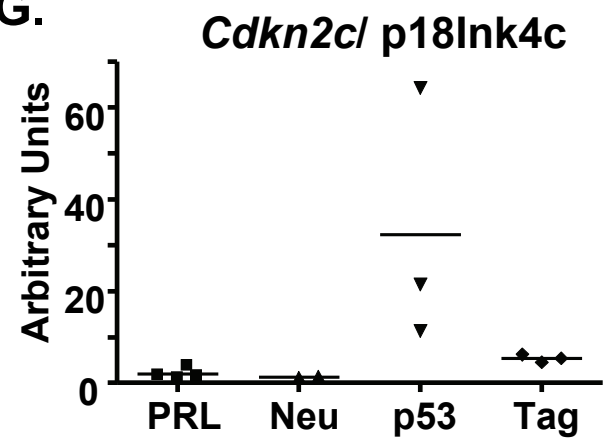

D.

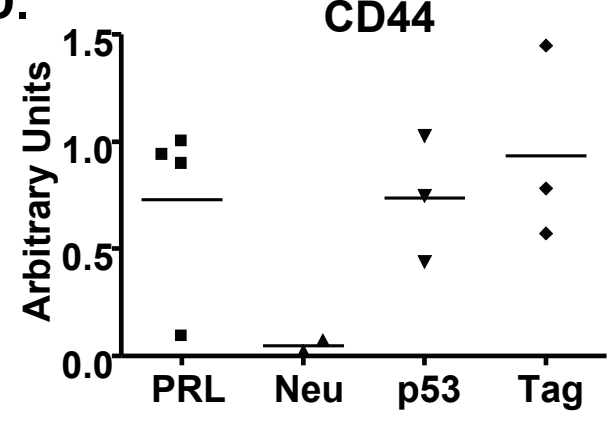

$\mathbf{F}$.

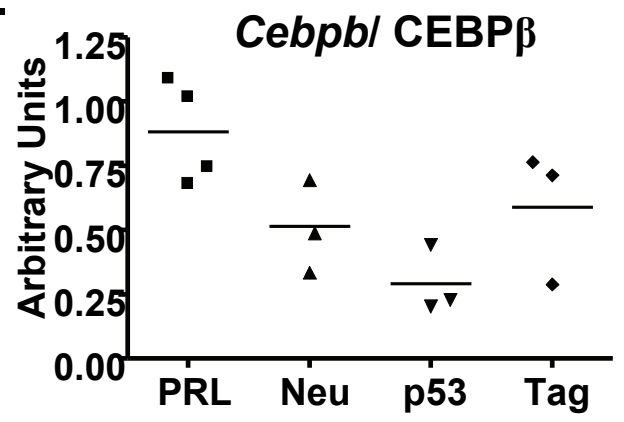

H.

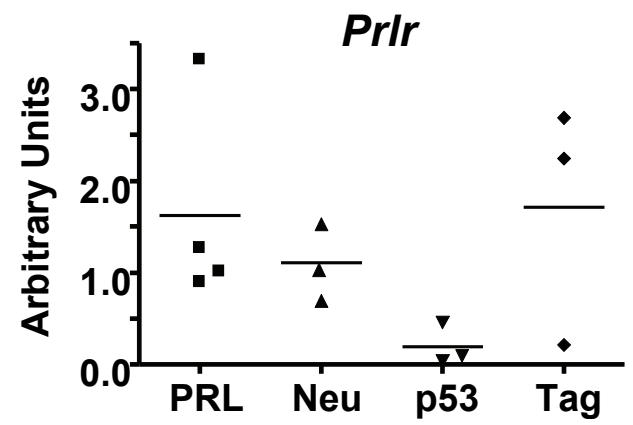

Figure 5 NRL-PRL adenocarcinomas express markers distinct from other well-characterized models of breast cancer. RNA from the set of mammary carcinomas in Figure 4 that developed in NRL-PRL, MMTV-neu [28], C3(1)-SV40 Tag [29], and transplanted p53 ${ }^{-1-}\left(\mathrm{O}^{\prime}\right.$ Leary and Schuler, manuscript in preparation) models was examined for levels of transcripts implicated in mammary lineages by qRT-PCR as described in the Materials and Methods. Each symbol denotes a distinct tumor. The horizontal bar indicates the mean level for each model. 
with ER $\alpha$ status (three papillary, two glandular, one adenosquamous, two solid). Genes that were differentially expressed among the classes were determined, and hierarchical clustering analyses were performed by comparing expression profiles both across the set of samples and across the set of genes. As shown in Figure 6a, $E R \alpha+$ and ER $\alpha$ - tumors clustered separately. Consistent with the reports of ER $\alpha+$ tumors in women, NRL-PRL $E R \alpha+$ tumors expressed higher levels of Gata-3 than $E R \alpha$ - tumors, and markers of differentiation, such as the milk proteins, $\beta$-casein and whey acidic protein, and CD24a [20,73-75]. Levels of mRNA for the PRL transgene and PRLR varied markedly among both ER $\alpha+$ and $E R \alpha$ - carcinomas, suggesting that PRL activity itself was not responsible for the differences observed (Figure S2 in Additional File 1).

Activity of the NRL-PRL promoter is not altered by estrogen [15], enabling us to examine the role of this steroid in the disease process. Proliferation of both morphologically normal MECs and preneoplastic epithelial hyperplasias in NRL-PRL females is very sensitive to ovariectomy (ovx) and supplemental estrogen [17,54]. In order to examine estrogen responsiveness in established carcinomas, NRL-PRL females bearing primary mammary adenocarcinomas were subjected to sham surgery or ovx. At the time of surgery, a biopsy was removed for examination of tumor histology, rate of proliferation, and steroid hormone receptor expression. The growth of the remaining tumors was monitored until they reached $1.5 \mathrm{~cm}$ in diameter $(15.3 \pm 8.5$ days; mean \pm s.d.), as described in the Materials and methods. Like the tumors in Figure 1, histotypes in this experimental panel were diverse, and ER $\alpha / P R$ expression varied widely. They exhibited highly variable rates of growth (Figure $6 \mathrm{~b}$ ); rates of proliferation of ER $\alpha$ - tumors prior to the surgery tended to be higher than ER $\alpha+$ tumors $(P=0.07)$. However, ovx did not alter rates of proliferation of either ER $\alpha+$ or ER $\alpha$ - tumor cells. Consistently, ovx followed by administration of E2 failed to alter proliferation of an independent set of primary tumors (PCNA staining: $30.1 \% \pm 12$ vs $31.19 \% \pm 7.9$, mean \pm s.d., $P>0.05, N=5$ ).

Since primary PRL-induced tumors exhibit highly variable histotype and ER $\alpha$ expression, and ovarian function is likely to be faltering in the aged females, we employed tumor transplantation to further investigate the role of $E R \alpha$-dependent signals in established tumors. We serially passaged NRL-PRL glandular adenocarcinoma fragments that demonstrated high expression of both ER $\alpha$ and PR ( $48 \%$ and $25 \%$ labeled cells, respectively) to bilateral inguinal mammary glands of nonparous 12 week-old syngeneic nontransgenic recipients. Although the tumors that grew from these fragments (about eight weeks per passage) retained the morphology and high
ER $\alpha$ expression of the original tumors, PR was no longer detectable after passage (not shown), suggesting that this process selects for more aggressive tumor cells. After three passages, recipient females were treated with ovx, sham surgery, or sham surgery and the ER $\alpha$-selective antagonist, Faslodex. None of these treatments altered rates of proliferation of the tumors, as measured by BrdU incorporation (Figure 6c), indicating that relatively well-differentiated $E R \alpha+$ tumors display the estrogen independence observed in the more diverse group of primary tumors.

These findings raise interesting questions regarding the mechanism(s) whereby PRL interacts with ER $\alpha$ mediated signals in the development and progression of $E R \alpha+$ tumors. The striking estrogen independence of established PRL-induced tumors shown herein contrasts with the cooperation between PRL and estrogen in proliferation of morphologically normal MECs and early lesions $[17,54]$, suggesting acquisition of estrogen insensitivity. Many primary clinical ER $\alpha+$ tumors acquire resistance to estrogen-directed therapies and most display marked therapeutic insensitivity after metastasis. A vast literature implicates many mechanisms, including aberrations not only of ER $\alpha$ itself, but alterations in other molecules and signaling pathways consistent with heightened growth factor activity [76-78]. The ability of PRL to potentiate growth factor signals [53-55,79] and high activation of AKT in the tumors shown here are consistent with a role in the latter mechanism. Clinically, high circulating PRL has been associated with failure of $E R \alpha+$ tumors to respond to tamoxifen and aromatase inhibitors [80-82], and PRLR transcripts were elevated with recurrence after tamoxifen treatment in some studies $[13,83]$. The histological heterogeneity and variable activation of signaling pathways of PRL-induced tumors observed here suggest that multiple mechanisms may lead to loss of estrogen sensitivity. Together, these features suggest that the NRL-PRL model may provide insight into the origin of the diversity of clinical ER $\alpha$ tumors, and the characteristics of the tumor subpopulation that resists therapy.

\section{Conclusions}

Despite the prevalence of ER $\alpha+$ tumors clinically, very few mouse models resemble this breast cancer subtype. Our studies demonstrate that elevated local PRL can promote diverse carcinomas, which display varying levels of ER $\alpha / \mathrm{PR}$, nuclear pStat5, pERK1/2 and pAKT, and AP-1 components. Transcript analysis demonstrates that many of these carcinomas express the ER $\alpha$-associated transcript signature that defines this clinical tumor subtype, and suggests that they arise from the physiologic target cells of PRL. In contrast to morphologically normal structures and hyperplastic lesions, 


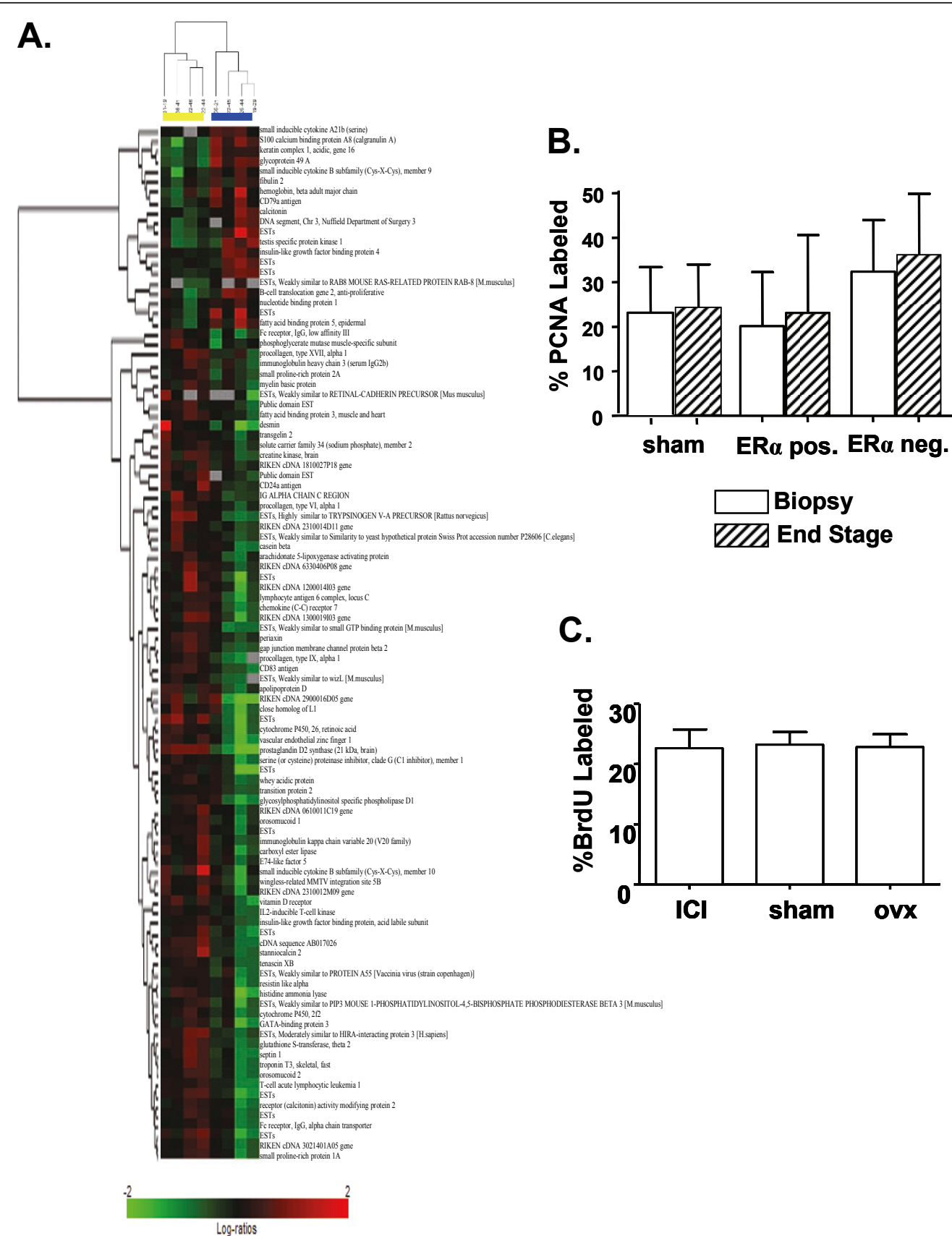

Figure $6 \mathrm{ER} \alpha+$ and $\mathrm{ER} \alpha$ - carcinomas demonstrate distinct transcript profiles, and are insensitive to ovarian steroids. (a) Hierarchical clustering of genes and tumor samples demonstrates differential expression between ER $\alpha+$ (yellow) and $E R \alpha$ - (blue) adenocarcinomas at the $P<0.01$ significance level $(N=4$ each). ER $\alpha+$ was defined as $\geq 10 \%$ of the cells contained detectable ER $\alpha$ by IHC; ER $\alpha$ - contained $<10 \%$. Red indicates high relative expression in ER $\alpha$ positive adenocarcinomas; green, low relative expression; black, no difference. Each column represents an independent tumor, and each row is a gene. (b) Growth of PRL-induced tumors is not diminished by ovariectomy, regardless of ER $\alpha$ status. Mammary carcinomas of distributed histotypes in NRL-PRL nonparous females were biopsied, and the mice subjected to sham surgery or ovariectomy. Subsequent tumor growth was monitored until tumors reached $1.5 \mathrm{~cm}$ in diameter $(15.3 \pm 8.5$ days; mean \pm s.d.), and proliferation determined by PCNA IHC as described in the Materials and Methods. Sham, $N=12$; ovx ER $\alpha+, N=10$; ovx ER $\alpha-, N=9$. Treatment did not alter the rate of growth (Student's paired $t$-test, $P>0.05$ ). (c) Treatment with the ER inhibitor and downregulator, Faslodex (ICl 182,780), does not inhibit growth of ER $\alpha$ positive tumor fragments. Fragments of well-differentiated ER $\alpha+$ tumors were transplanted into fat pads of nontransgenic recipients and treated with ovariectomy, sham surgery, or Faslodex as described in Materials and Methods. Ovariectomized and Faslodex-treated females had significantly reduced uterine weights ( $27 \pm 5 \mathrm{mg}, 30 \pm 8 \mathrm{mg}$, mean \pm s.d., respectively), compared to sham-treated females ( $83 \pm 5$ mg). Treatment did not alter the rate of proliferation $(P>0.05)$. 
established carcinomas are strikingly insensitive to estrogen, suggesting acquisition of independence. The role of ongoing PRL signals in established tumors will require additional investigation. Recent studies suggest that PRL also can antagonize traditional chemotherapeutics in breast cancer cells in vitro $[84,85]$, which is supported by small studies of PRL on therapeutic resistance in vivo [86]. Together, our findings suggest that the NRL-PRL mammary tumor model will be helpful to understand the pathogenesis and heterogeneity of luminal tumors and identify factors determining susceptibility to antiestrogen and traditional chemotherapies, to examine the role of PRL in these responses, and to test novel therapeutic strategies, including combinatorial regimens including therapies directed at PRL.

\section{Additional material}

Additional file 1: Supplementary tables and figures. Table S1: Immunohistochemistry conditions. Description of retrieval methods, blocking conditions and antibody dilutions used for each antigen examined. Table S2: Primers employed for RT-PCR analyses. Sequences of the primers used to quantify transcripts of interest. Figure S1: PRLinduced carcinomas of different histotypes display variable levels of transcripts for ER $\alpha$-associated genes. Levels of mRNA for various transcripts of interest in individual PRL-induced tumors of different histotypes, determined by qRT-PCR. Figure S2: Levels of transgene and Prlr transcripts are variable in NRL-PRL adenocarcinomas, and are not associated with ER $\alpha$ status. Levels of mRNA for rPRL transgene and cytokeratin 8 (Krt8), and PRL receptor in individual tumors, determined by $\mathrm{qRT}-\mathrm{PCR}$.

\section{Abbreviations}

AP-1: Activating Protein 1; BrdU: bromodeoxyuridine; EMT: epithelial mesenchymal transition; ERa: estrogen receptor alpha; ERK: extracellular signal regulated kinase; IHC: immunohistochemistry; MECs: mammary epithelial cells; MMTV: mouse mammary tumor virus; PCNA: proliferating cell nuclear antigen; PR: progesterone receptor; PRL: prolactin; PRLR: prolactin receptor; qRT-PCR: quantitative reverse-transcriptase polymerase chain reaction; NRL: neu-related lipocalin; Stat5: signal transducer and activator of transcription 5

\section{Acknowledgements}

The authors thank Dr. Charles Perou and George Murrow (University of North Carolina, Chapel Hill) for assistance with the microarray analyses. We are grateful to Lindsay Evans for technical assistance, Dr. Chris Bradfield and his laboratory for assistance with the Agilent Bioanalyzer, and Dr. Jen-Te Wang from Agilent for the gift of the microarrays. We appreciate the generous gifts of mammary tumors from other transgenic models, as well as helpful discussions from Drs. Soyoung Kim and Caroline Alexander, Zi-Yao Liu and Jeffrey Green, and Kathleen O'Leary.

This publication was made possible by grant number K01 RR021858 (L.M.A.) from the National Center for Research Resources (NCRR), a component of the National Institutes of Health (NIH), NIH Grants R01 CA78312 and DK62783 (L.A.S.), R01 CA118740 (H.R.) and T32 AG00265.

\section{Author details}

'Department of Comparative Biosciences, University of Wisconsin-Madison, 2015 Linden Dr., Madison, WI 53706, USA. ²Department of Cancer Biology, Kimmel Cancer Center, Thomas Jefferson University, 233 South 10th St, 332 BLSB, Philadelphia, PA 19107, USA. ${ }^{3}$ Department of Anatomy \& Cellular Biology, Sackler School, Tufts University School of Medicine, 136 Harrison
Ave, Boston, MA 02111, USA. ${ }^{4}$ Genetics Department, Navarra University, Irunlarrea St. 1, Pamplona, 31008, Spain.

\section{Authors' contributions}

LMA and LAS contributed to concept design, data analysis and interpretation, and manuscript writing. DER carried out the transcript analyses and contributed to interpretation. TAG-H contributed to the generation of experimental data and analysis. MJG-B and HR analyzed the pStat5 expression of the tumors. All authors read and approved the final manuscript.

\section{Competing interests}

The authors declare that they have no competing interests.

Received: 5 September 2010 Revised: 30 November 2010

Accepted: 28 January 2011 Published: 28 January 2011

\section{References}

1. Oakes SR, Rogers RL, Naylor MJ, Ormandy CJ: Prolactin regulation of mammary gland development. J Mammary Gland Biol Neoplasia 2008, 13:13-28.

2. Tworoger SS, Hankinson SE: Prolactin and breast cancer etiology: an epidemiologic perspective. J Mammary Gland Biol Neoplasia 2008, 13:41-53.

3. Bhatavdekar JM, Patel DD, Shah NG, Vora HH, Suthar TP, Chikhlikar PR, Ghosh N, Trivedi TI: Prognostic significance of immunohistochemically localized biomarkers in stage II and stage III breast cancer: a multivariate analysis. Ann Surg Oncol 2000, 7:305-311.

4. Clevenger CV, Zheng J, Jablonski EM, Galbaugh TL, Fang F: From bench to bedside: future potential for the translation of prolactin inhibitors as breast cancer therapeutics. J Mammary Gland Biol Neoplasia 2008, 13:147-156.

5. McHale K, Tomaszewski JE, Puthiyaveettil R, Livolsi VA, Clevenger CV: Altered expression of prolactin receptor-associated signaling proteins in human breast carcinoma. Mod Pathol 2008, 21:565-571.

6. Bhatavdekar JM, Patel DD, Shah NG, Vora HH, Suthar TP, Ghosh N, Chikhlikar PR, Trivedi TI: Prolactin as a local growth promoter in patients with breast cancer: GCRI experience. Eur J Surg Oncol 2000, 26:540-547.

7. Canbay E, Degerli N, Gulluoglu BM, Kaya H, Sen M, Bardakci F: Could prolactin receptor gene polymorphism play a role in pathogenesis of breast carcinoma? Curr Med Res Opin 2004, 20:533-540.

8. Vaclavicek A, Hemminki K, Bartram CR, Wagner K, Wappenschmidt B, Meindl A, Schmutzler RK, Klaes R, Untch M, Burwinkel B, Forsti A: Association of prolactin and its receptor gene regions with familial breast cancer. J Clin Endocrinol Metab 2006, 91:1513-1519.

9. Lee SA, Haiman CA, Burtt NP, Pooler LC, Cheng I, Kolonel LN, Pike MC, Altshuler D, Hirschhorn JN, Henderson BE, Stram DO: A comprehensive analysis of common genetic variation in prolactin (PRL) and PRL receptor (PRLR) genes in relation to plasma prolactin levels and breast cancer risk: the multiethnic cohort. BMC Med Genet 2007, 8:72.

10. Utama FE, Tran TH, Ryder A, LeBaron MJ, Parlow AF, Rui H: Insensitivity of human prolactin receptors to non-human prolactins: Relevance for experimental modeling of prolactin receptor-expressing human cells. Endocrinology 2009, 150:1782-1790.

11. Perry JK, Mohankumar KM, Emerald BS, Mertani HC, Lobie PE: The contribution of growth hormone to mammary neoplasia. J Mammary Gland Biol Neoplasia 2008, 13:131-145.

12. Swaminathan G, Varghese B, Fuchs SY: Regulation of prolactin receptor levels and activity in breast cancer. J Mammary Gland Biol Neoplasia 2008, 13:81-91.

13. Rhodes DR, Kalyana-Sundaram S, Mahavisno V, Varambally R, Yu J, Briggs BB, Barrette TR, Anstet MJ, Kincead-Beal C, Kulkarni P, Varambally S, Ghosh D, Chinnaiyan AM: Oncomine 3.0: genes, pathways, and networks in a collection of 18,000 cancer gene expression profiles. Neoplasia 2007, 9:166-180.

14. Rose-Hellekant TA, Arendt LM, Schroeder MD, Gilchrist K, Sandgren EP, Schuler LA: Prolactin induces ERa-positive and ERa-negative mammary cancer in transgenic mice. Oncogene 2003, 22:4664-4674.

15. Rose-Hellekant TA, Schroeder MD, Brockman JL, Zhdankin O, Bolstad R, Chen KS, Gould MN, Schuler LA, Sandgren EP: Estrogen receptor positive 
mammary tumorigenesis in TGFa transgenic mice progresses with progesterone receptor loss. Oncogene 2007, 26:5238-5246.

16. Arendt LM, Schuler LA: Transgenic models to study actions of prolactin in mammary neoplasia. J Mammary Gland Biol Neoplasia 2008, 13:29-40.

17. Arendt LM, Evans LC, Rugowski DE, Garcia-Barchino MJ, Rui H, Schuler LA: Ovarian hormones are not required for PRL-induced mammary tumorigenesis, but estrogen enhances neoplastic processes. J Endocrinol 2009, 203:99-110.

18. Early Breast Cancer Trialists' Collaborative Group: Effects of chemotherapy and hormonal therapy for early breast cancer on recurrence and 15-year survival: an overview of the randomised trials. Lancet 2005, 365:1687-1717.

19. Perou CM, Borresen-Dale AL: Systems biology and genomics of breast cancer. Cold Spring Harb Perspect Biol 2010.

20. Hu Z, Fan C, Oh DS, Marron JS, He X, Qaqish BF, Livasy C, Carey LA, Reynolds E, Dressler L, Nobel A, Parker J, Ewend MG, Sawyer LR, Wu J, Liu Y, Nanda R, Tretiakova M, Ruiz OA, Dreher D, Palazzo JP, Perreard L, Nelson E, Mone M, Hansen H, Mullins M, Quackenbush JF, Ellis MJ, Olopade Ol, Bernard PS, et al: The molecular portraits of breast tumors are conserved across microarray platforms. BMC Genomics 2006, 7:96.

21. Van de Vijver MJ, He YD, Van't Veer LJ, Dai H, Hart AA, Voskuil DW, Schreiber GJ, Peterse JL, Roberts C, Marton MJ, Parrish M, Atsma D, Witteveen A, Glas A, Delahaye L, van d V, Bartelink H, Rodenhuis S, Rutgers ET, Friend SH, Bernards R: A gene-expression signature as a predictor of survival in breast cancer. N Engl J Med 2002, 347:1999-2009.

22. Paik S, Tang G, Shak S, Kim C, Baker J, Kim W, Cronin M, Baehner FL, Watson D, Bryant J, Costantino JP, Geyer CE Jr, Wickerham DL, Wolmark N: Gene expression and benefit of chemotherapy in women with nodenegative, estrogen receptor-positive breast cancer. J Clin Oncol 2006, 24:3717-3718.

23. Perreard L, Fan C, Quackenbush JF, Mullins M, Gauthier NP, Nelson E, Mone M, Hansen H, Buys SS, Rasmussen K, Orrico AR, Dreher D, Walters R, Parker J, Hu Z, He X, Palazzo JP, Olopade OI, Szabo A, Perou CM, Bernard PS: Classification and risk stratification of invasive breast carcinomas using a real-time quantitative RT-PCR assay. Breast Cancer Res 2006, 8:R23.

24. Visvader JE: Keeping abreast of the mammary epithelial hierarchy and breast tumorigenesis. Genes Dev 2009, 23:2563-2577.

25. Prat A, Perou CM: Mammary development meets cancer genomics. Nat Med 2009, 15:842-844.

26. Jacks T, Remington L, Williams BO, Schmitt EM, Halachmi S, Bronson RT, Weinberg RA: Tumor spectrum analysis in p53-mutant mice. Curr Biol 1994, 4:1-7.

27. Hasen NS, O'Leary KA, Auger AP, Schuler LA: Social isolation reduces mammary development, tumor incidence and expression of epigenetic regulators in wild type and p53-heterozygotic mice. Cancer Prev Res 2010, 3:620-629.

28. Guy CT, Webster MA, Schaller M, Parsons TJ, Cardiff RD, Muller WJ: Expression of the neu protooncogene in the mammary epithelium of transgenic mice induces metastatic disease. Proc Natl Acad Sci USA 1992, 89:10578-10582

29. Green JE, Shibata MA, Yoshidome K, Liu ML, Jorcyk C, Anver MR, Wigginton J, Wiltrout R, Shibata E, Kaczmarczyk S, Wang W, Liu ZY, Calvo A, Couldrey C: The C3(1)/SV40 T-antigen transgenic mouse model of mammary cancer: ductal epithelial cell targeting with multistage progression to carcinoma 2. Oncogene 2000, 19:1020-1027.

30. Nevalainen MT, Xie JW, Bubendorf $L$, Wagner KU, Rui H: Basal activation of transcription factor Stat5 in nonpregnant mouse and human breast epithelium. Mol Endocrinol 2002, 16:1108-1124.

31. Herschkowitz JI, Simin K, Weigman VJ, Mikaelian I, Usary J, Hu Z, Rasmussen KE, Jones LP, Assefnia S, Chandrasekharan S, Backlund MG, Yin Y, Khramtsov Al, Bastein R, Quackenbush J, Glazer Rl, Brown PH, Green JE, Kopelovich L, Furth PA, Palazzo JP, Olopade OI, Bernard PS, Churchill GA, van Dyke T, Perou CM: Identification of conserved gene expression features between murine mammary carcinoma models and human breast tumors. Genome Biol 2007, 8:R76.

32. Emerman JT, Bissell MJ: Cultures of mammary epithelial cells: extracellular matrix and functional differentiation. Adv Cell Culture 1988, 6:137-159.

33. Gupta PB, Proia D, Cingoz O, Weremowicz J, Naber SP, Weinberg RA, Kuperwasser C: Systemic stromal effects of estrogen promote the growth of estrogen receptor-negative cancers. Cancer Res 2007, 67:2062-2071.
34. Wagner $\mathrm{KU}$, Rui H: Jak2/Stat5 signaling in mammogenesis, breast cancer initiation and progression. J Mammary Gland Biol Neoplasia 2008, 13:93-103.

35. Gutzman JH, Rugowski DE, Nikolai SE, Schuler LA: Stat5 activation inhibits prolactin-induced AP-1 activity: distinct prolactin initiated signals in tumorigenesis dependent on cell context. Oncogene 2007, 26:6341-6348.

36. Gutzman JH, Rugowski DE, Schroeder MD, Watters JJ, Schuler LA: Multiple kinase cascades mediate prolactin signals to activating protein-1 in breast cancer cells. Mol Endocrinol 2004, 18:3064-3075.

37. Shaulian E, Karin M: AP-1 as a regulator of cell life and death. Nat Cell Biol 2002, 4:E131-E136.

38. Eferl R, Wagner EF: AP-1: a double-edged sword in tumorigenesis. Nature Reviews Cancer 2003, 3:859-868

39. Ozanne BW, Spence HJ, McGarry LC, Hennigan RF: Transcription factors control invasion: AP-1 the first among equals. Oncogene 2007, 26:1-10.

40. Robinson GW, McKnight RA, Smith GH, Hennighausen L: Mammary epithelial cells undergo secretory differentiation in cycling virgins but require pregnancy for the establishment of terminal differentiation. Development 1995, 121:2079-2090.

41. Harris J, Stanford PM, Sutherland K, Oakes SR, Naylor MJ, Robertson FG, Blazek KD, Kazlauskas M, Hilton HN, Wittlin S, Alexander WS, Lindeman GJ, Visvader JE, Ormandy CJ: Socs2 and Elf5 mediate prolactin-induced mammary gland development. Mol Endocrinol 2006, 20:1177-1187.

42. Wu ZS, Wu Q, Yang JH, Wang HQ, Ding XD, Yang F, Xu XC: Prognostic significance of MMP-9 and TIMP-1 serum and tissue expression in breast cancer. Int J Cancer 2008, 122:2050-2056.

43. Whyte J, Bergin O, Bianchi A, McNally S, Martin F: Key signalling nodes in mammary gland development and cancer. Mitogen-activated protein kinase signalling in experimental models of breast cancer progression and in mammary gland development. Breast Cancer Res 2009, 11:209.

44. Thiery JP, Sleeman JP: Complex networks orchestrate epithelialmesenchymal transitions. Nat Rev Mol Cell Biol 2006, 7:131-142.

45. Turley EA, Veiseh M, Radisky DC, Bissell MJ: Mechanisms of disease: epithelial-mesenchymal transition-does cellular plasticity fuel neoplastic progression? Nat Clin Pract Oncol 2008, 5:280-290.

46. Dillon RL, White DE, Muller WJ: The phosphatidyl inositol 3-kinase signaling network: implications for human breast cancer. Oncogene 2007, 26:1338-1345.

47. Tokunaga E, Kataoka A, Kimura Y, Oki E, Mashino K, Nishida K, Koga T, Morita M, Kakeji Y, Baba H, Ohno S, Maehara Y: The association between Akt activation and resistance to hormone therapy in metastatic breast cancer. Eur J Cancer 2006, 42:629-635.

48. Kirkegaard T, Witton CJ, McGlynn LM, Tovey SM, Dunne B, Lyon A, Bartlett JM: AKT activation predicts outcome in breast cancer patients treated with tamoxifen. J Pathol 2005, 207:139-146.

49. Sakamoto K, Triplett AA, Schuler LA, Wagner KU: Jak2 is required for the initiation but not maintenance of prolactin-induced mammary cancer. Oncogene 2010, 29:5359-5369.

50. Schiff R, Reddy P, Ahotupa M, Coronado-Heinsohn E, Grim M, Hilsenbeck SG, Lawrence R, Deneke S, Herrera R, Chamness GC, Fuqua SA, Brown $\mathrm{PH}$, Osborne CK: Oxidative stress and AP-1 activity in tamoxifenresistant breast tumors in vivo. J Natl Cancer Inst 2000, 92:1926-1934.

51. Vendrell JA, Robertson KE, Ravel P, Bray SE, Bajard A, Purdie CA, Nguyen C, Hadad SM, Bieche I, Chabaud S, Bachelot T, Thompson AM, Cohen PA: A candidate molecular signature associated with tamoxifen failure in primary breast cancer. Breast Cancer Res 2008, 10:R88.

52. Creighton CJ, Kent OC, Van de Vijver MJ, Foekens JA, Klijn JG, Horlings HM, Nuyten D, Wang Y, Zhang Y, Chamness GC, Hilsenbeck SG, Lee AV, Schiff R: Molecular profiles of progesterone receptor loss in human breast tumors. Breast Cancer Res Treat 2008, 114:287-299.

53. Arendt LM, Rose-Hellekant TA, Sandgren EP, Schuler LA: Prolactin potentiates TGFa induction of mammary neoplasia in transgenic mice. Am J Pathol 2006, 168:1365-1374.

54. Arendt LM, Grafwallner-Huseth TL, Schuler LA: Prolactin-growth factor crosstalk reduces mammary estrogen responsiveness despite elevated ERa expression. Am J Pathol 2009, 174:1065-1074.

55. Carver KC, Schuler LA: Prolactin does not require insulin-like growth factor (IGF) intermediates, but synergizes with IGF-1 in human breast cancer cells. Mol Cancer Res 2008, 6:634-643.

56. Carroll JS, Liu XS, Brodsky AS, Li W, Meyer CA, Szary AJ, Eeckhoute J, Shao W, Hestermann EV, Geistlinger TR, Fox EA, Silver PA, Brown M: 
Chromosome-wide mapping of estrogen receptor binding reveals longrange regulation requiring the forkhead protein FoxA1. Cell 2005, 122:33-43.

57. Bernardo GM, Lozada KL, Miedler JD, Harburg G, Hewitt SC, Mosley JD, Godwin AK, Korach KS, Visvader JE, Kaestner KH, Abdul-Karim FW, Montano MM, Keri RA: FOXA1 is an essential determinant of ERalpha expression and mammary ductal morphogenesis. Development 2010, 137:2045-2054.

58. Ursini-Siegel J, Schade B, Cardiff RD, Muller WJ: Insights from transgenic mouse models of ERBB2-induced breast cancer. Nat Rev Cancer 2007, 7:389-397.

59. Vaillant F, Asselin-Labat ML, Shackleton M, Forrest NC, Lindeman GJ, Visvader JE: The mammary progenitor marker CD61/beta3 integrin identifies cancer stem cells in mouse models of mammary tumorigenesis. Cancer Res 2008, 68:7711-7717.

60. Henry MD, Triplett AA, Oh KB, Smith GH, Wagner KU: Parity-induced mammary epithelial cells facilitate tumorigenesis in MMTV-neu transgenic mice. Oncogene 2004, 23:6980-6985.

61. Deeb KK, Michalowska AM, Yoon CY, Krummey SM, Hoenerhoff MJ, Kavanaugh C, Li MC, DeMayo FJ, Linnoila I, Deng CX, Lee EY, Medina D, Shih JH, Green JE: Identification of an integrated SV40 T/t-antigen cancer signature in aggressive human breast, prostate, and lung carcinomas with poor prognosis. Cancer Res 2007, 67:8065-8080.

62. Kouros-Mehr H, Kim JW, Bechis SK, Werb Z: GATA-3 and the regulation of the mammary luminal cell fate. Curr Opin Cell Biol 2008, 20:164-170.

63. Stingl J: Detection and analysis of mammary gland stem cells. J Pathol 2009, 217:229-241.

64. Godar S, Ince TA, Bell GW, Feldser D, Donaher UL, Bergh J, Liu A, Miu K, Watnick RS, Reinhardt F, McAllister SS, Jacks T, Weinberg RA: Growthinhibitory and tumor- suppressive functions of $\mathrm{p} 53$ depend on its repression of CD44 expression. Cell 2008, 134:62-73.

65. Wang Y, Klijn JG, Zhang Y, Sieuwerts AM, Look MP, Yang F, Talantov D, Timmermans M, Meijer-van Gelder ME, Yu J, Jatkoe T, Berns EM, Atkins D, Foekens JA: Gene-expression profiles to predict distant metastasis of lymph-node-negative primary breast cancer. Lancet 2005, 365:671-679.

66. Grimm SL, Seagroves TN, Kabotyanski EB, Hovey RC, Vonderhaar BK, Lydon JP, Miyoshi K, Hennighausen L, Ormandy CJ, Lee AV, Stull MA, Wood TL, Rosen JM: Disruption of steroid and prolactin receptor patterning in the mammary gland correlates with a block in lobuloalveolar development. Mol Endocrinol 2002, 16:2675-2691.

67. Oakes SR, Naylor MJ, Asselin-Labat ML, Blazek KD, Gardiner-Garden M, Hilton HN, Kazlauskas M, Pritchard MA, Chodosh LA, Pfeffer PL, Lindeman GJ, Visvader JE, Ormandy CJ: The Ets transcription factor Elf5 specifies mammary alveolar cell fate. Genes Dev 2008, 22:581-586.

68. LaMarca HL, Visbal AP, Creighton CJ, Liu H, Zhang Y, Behbod F, Rosen JM: C/EBPbeta regulates stem cell activity and specifies luminal cell fate in the mammary gland. Stem Cells 2010, 28:535-544.

69. Yamaji D, Na R, Feuermann Y, Pechhold S, Chen W, Robinson GW Hennighausen L: Development of mammary luminal progenitor cells is controlled by the transcription factor STAT5A. Genes Dev 2009, 23:2382-2387.

70. Pei XH, Bai F, Smith MD, Usary J, Fan C, Pai SY, Ho IC, Perou CM, Xiong Y: CDK inhibitor p18(INK4C) is a downstream target of GATA3 and restrains mammary luminal progenitor cell proliferation and tumorigenesis. Cancer Cell 2009, 15:389-401.

71. Brockman $\mathrm{J}$, Schroeder MD, Schuler LA: Prolactin activates the cyclin D1 promoter via the JAK2-STAT pathway. Mol Endocrinol 2002, 16:774-784.

72. Lim E, Vaillant F, Wu D, Forrest NC, Pal B, Hart AH, Asselin-Labat ML, Gyorki DE, Ward T, Partanen A, Feleppa F, Huschtscha LI, Thorne HJ, Fox SB, Yan M, French JD, Brown MA, Smyth GK, Visvader JE, Lindeman GJ: Aberrant luminal progenitors as the candidate target population for basal tumor development in BRCA1 mutation carriers. Nat Med 2009, 15:907-913.

73. Gruvberger S, Ringnér $M$, Chen YD, Panavally S, Saal LH, Borg Å, Fernö M, Peterson C, Meltzer PS: Estrogen receptor status in breast cancer is associated with remarkably distinct gene expression patterns. Cancer Res 2001, 61:5979-5984.

74. Van't Veer L, Dai HY, Van de Vijver MJ, He YDD, Hart AAM, Mao M, Peterse HL, Van der Kooy K, Marton MJ, Witteveen AT, Schreiber GJ, Kerkhoven RM, Roberts C, Linsley PS, Bernards R, Friend SH: Gene expression profiling predicts clinical outcome of breast cancer. Nature 2002, 415:530-536.

75. Sorlie T: Molecular portraits of breast cancer: tumour subtypes as distinct disease entities. Eur J Cancer [A] 2004, 40:2667-2675.

76. Ali S, Coombes RC: Endocrine-responsive breast cancer and strategies for combating resistance. Nat Rev Cancer 2002, 2:101-112.

77. Musgrove EA, Sutherland RL: Biological determinants of endocrine resistance in breast cancer. Nat Rev Cancer 2009, 9:631-643.

78. Nicholson Rl, Hutcheson IR, Jones HE, Hiscox SE, Giles M, Taylor KM, Gee JM: Growth factor signalling in endocrine and anti-growth factor resistant breast cancer. Rev Endocr Metab Disord 2007, 8:241-253.

79. Carver KC, Arendt LM, Schuler LA: Complex prolactin crosstalk in breast cancer: new therapeutic implications. Mol Cell Endocrinol 2009, 307:1-7.

80. Barni S, Lissoni P, Meregalli S, Ardizzoia A, Mengo S, Musco F, Merlini D, Tancini G: Clinical efficacy of the aromatase inhibitor anastrozole in relation to prolactin secretion in heavily pretreated metastatic breast cancer. Tumori 1998, 84:45-47.

81. Bhatavdekar JM, Patel DD, Karelia NH, Shah NG, Ghosh N, Vora HH, Suthar TP, Balar DB, Doctor SS: Can plasma prolactin predict tamoxifen resistance in patients with advanced breast cancer? Eur J Surg Oncol 1994, 20:118-121.

82. Dowsett M, McGarrick GE, Harris AL, Coombes RC, Smith IE, Jeffcoate SL: Prognostic significance of serum prolactin levels in advanced breast cancer. Br J Cancer 1983, 47:763-769.

83. Ma XJ, Salunga R, Tuggle JT, Gaudet J, Enright E, McQuary P, Payette T, Pistone M, Stecker K, Zhang BM, Zhou YX, Varnholt H, Smith B, Gadd M, Chatfield E, Kessler J, Baer TM, Erlander MG, Sgroi DC: Gene expression profiles of human breast cancer progression. Proc Natl Acad Sci USA 2003, 100:5974-5979.

84. LaPensee EW, Schwemberger SJ, LaPensee CR, Bahassi EM, Afton S, BenJonathan N: Prolactin confers resistance against cisplatin in breast cancer cells by activating glutathione-S-transferase. Carcinogenesis 2009, 30:1298-1304.

85. Howell SJ, Anderson E, Hunter T, Farnie G, Clarke RB: Prolactin receptor antagonism reduces the clonogenic capacity of breast cancer cells and potentiates doxorubicin and paclitaxel cytotoxicity. Breast Cancer Res 2008, 10:R68.

86. Frontini L, Lissoni P, Vaghi M, Perego MS, Pescia S, Ardizzoia A, Gardani G Enhancement of the efficacy of weekly low-dose taxotere by the long acting anti-prolactinemic drug cabergoline in pretreated metastatic breast cancer. Anticancer Res 2004, 24:4223-4226.

doi:10.1186/bcr2819

Cite this article as: Arendt et al:: Prolactin-induced mouse mammary carcinomas model estrogen resistant luminal breast cancer. Breast Cancer Research 2011 13:R11.

\section{Submit your next manuscript to BioMed Central and take full advantage of:}

- Convenient online submission

- Thorough peer review

- No space constraints or color figure charges

- Immediate publication on acceptance

- Inclusion in PubMed, CAS, Scopus and Google Scholar

- Research which is freely available for redistribution

Submit your manuscript at www.biomedcentral.com/submit
C Biomed Central 